\title{
In vitro Neuronal Differentiation of Drosophila Embryo Cells
}

\author{
Paul M. Salvaterra, ${ }^{1}$ Nicole Bournias-Vardiabasis, ${ }^{2}$ Tina Nair, ${ }^{1}$ Grace Hou, ${ }^{1}$ and Cheryl Lieu ${ }^{1}$ \\ 'Division of Neurosciences, Beckman Research Institute of the City of Hope, and 'Division of Cytogenetics, City of Hope \\ National Medical Center, Duarte, California 91010
}

Early gastrula-stage Drosophila embryo cells will differentiate in vitro to form several cell types, including neurons. We report here the morphological appearance of cultured embryo cells, the pattern of DNA synthesis, and the expression of neurotransmitter-metabolizing macromolecules. The cells initially exhibit no overt morphological differentiation, and all cells incorporate ${ }^{3} \mathrm{H}$-thymidine following a $1 \mathrm{hr}$ pulselabeling period. As cells undergo morphological differentiation, fewer total cells as well as qualitatively different cell types incorporate label. By the time cells are 8 or 9 hr old, no myocytes or myotubes are labeled. In contrast, some neurons are labeled with a thymidine pulse as late as $18 \mathrm{hr}$. We have also stained cultured cells of various developmental ages with the insect neuron-specific antibody: antiHRP. Some positive cells can be detected as early as $5 \mathrm{hr}$, when no overt morphological differentiation is apparent. As the cells differentiate, the staining is limited to the small, round neuronal type and its processes. These findings suggest that this neuron-specific cell marker is expressed very early in cultured gastrula-stage cells and may be used to identify neuronal precursor cells. We have studied the patterns of expression of several macromolecules involved in acetylcholine metabolism using these cultures. The appearance of choline acetyltransferase (ChAT), the biosynthetic enzyme for ACh production, is first detected in 5-hrold cells. There is an initial phase of low-level expression, followed by a rapid rise in activity shortly after the differentiating neuron clusters make contact with one another. ChAT activity reaches a plateau in 36-48-hr-old cells. Acetylcholinesterase activity can be detected several hours before ChAT and also shows a period of low-level expression followed by a rapidly increasing phase, reaching a plateau at around $36-48 \mathrm{hr}$. ${ }^{125} \mathrm{I}-\alpha$-bungarotoxin binding appears in cells about $4 \mathrm{hr}$ old and rapidly approaches maximum levels by about $36 \mathrm{hr}$. The in vitro expression pattern for ChAT and AChE is similar to that seen in vivo. AChE activity has been localized histochemically to the neurons and their processes in vitro.

The normal in vitro expression pattern for ChAT and AChE can be altered by adding various cholinergic drugs to the

\footnotetext{
Received Feb. 20, 1985; revised May 8, 1986; accepted July 1, 1986.

We wish to express our thanks to Rosalba Raygoza, Alison Cuyler, Noel Neighbor, and Josephine Flores for excellent technical assistance. Scanning electron micrographs were prepared in the Shared Instrumentation Laboratory using the Philips SEM 505, which was purchased with funds from the NIH (S10 RRO 146701). This work was supported by the Hurd Foundation and the NIH-NINCDS

Correspondence should be addressed to Paul M. Salvaterra, Ph.D., Division of Neurosciences, Beckman Research Institute of the City of Hope, 1450 East Duarte Road, Duarte, CA 91010.

Copyright (C) 1987 Society for Neuroscience $0270-6474 / 87 / 010010-13 \$ 02.00 / 0$
}

culture medium during cell differentiation. Medium conditioned by older cultures can also result in lower levels of ChAT and AChE expression. These results indlcate that the gene expression patterns for neurotransmitter metabolism can be influenced by environmental cues, thus making Drosophila embryo cultures an attractive preparation for the study of the genetic and epigenetic factors involved in neuronal development.

Development of the nervous system involves a complex interaction between genetic and epigenetic factors. In order to obtain a satisfactory understanding of development, it will be necessary to precisely define both of these factors, as well as their interactions. Early gastrula-stage embryo cells of Drosophila can be cultured under conditions in which they divide and form differentiated neurons (Seecof and Unanue, 1968; Seecof et al., 1971, 1973a; Shields et al., 1975). Thus, these cultures offer a unique biological preparation for studying many aspects of early neurogenesis. Drosophila studies have the powerful advantage of well-defined genetics; several genes controlling neurogenesis have already been described (Wright, 1970; Jimenez and Campos-Ortega, 1979; White, 1980; Lehman et al., 1981; CamposOrtega, 1982). When early gastrula-stage cells are grown in vitro, it is possible to examine the effects of embryonic-lethal mutations (which are likely to include most neurogenesic mutants) at the cellular level. In addition, an in vitro paradigm allows the environment to be both defined and manipulated in order to uncover the various epigenctic factors controlling development.

Since the pioneering studies of Seecof and his collaborators (Seecof and Unanue, 1968; Seecof et al., 1972, 1973a-c) and Sang (Shields and Sang, 1970; Shields et al., 1975), few investigators have taken advantage of Drosophila embryo cell cultures. These early studies provided evidence that embryonic gastrulastage cells could differentiate in vitro to form morphologically and functionally defined neurons and myotubes. In addition, Dewhurst and Seecof $(1975,1979)$ provided evidence for the in vitro expression of enzymes involved in $\mathrm{ACh}$ metabolism in differentiating embryo cell cultures. More recent studies using this cell culture system have focused on its potential as an in vitro eucaryotic teratogen-screening system (Bournias-Vardiabasis et al., 1983a, b) and the role of heat-shock proteins during embryonic development (Buzin and Bournias-Vardiabasis, 1984). Furst and Mahowald (1984) have employed differentiated embryo cell cultures as an immunohistochemical screening assay for the identification of cell type-specific monoclonal antibodies raised in response to complex Drosophila immunogens. In addition, they have recently described a method for purifying primary embryonic neuroblasts from dissociated embryo cells (Furst and Mahowald, 1985a), thus allowing culture 
of a pure neuroblast population. They have also recently characterized the pattern of DNA synthesis in cultures enriched in neuronal precursor cells (Furst and Mahowald, 1985b).

Jan and Jan (1982) have described the curious and potentially useful in vivo appearance of a neuronal cell type-specific antigen that can be recognized by antibodies raised against the soluble enzyme HRP. We have studied the immunohistochemical appearance of this insect neuron-specific marker in vitro as a function of the developmental age of cultured gastrula-stage embryo cells. Our results provide additional evidence for a chemical neuronal differentiation program operating in embryo cell cultures. We have also characterized the kinetics of ${ }^{3} \mathrm{H}$-thymidine deoxyribose (TdR) incorporation into cultured gastrula-stage cells by pulse-labeling cultures at various developmental stages, and have followed this with quantitative measurements or radioautography.

One of the most fundamental actions of a neuron during devclopment involves the choice of an appropriate ncurotransmitter. A complex array of genetic and epigenetic factors must operate in order for each neuron to both make the appropriate choice and enforce it throughout its lifetime. The precise mechanisms that regulate initial neurotransmitter phenotype selection and maintenance are not known. However, there has been a great deal of investigation in this area, pioneered by the elegant in vivo studies of LeDourain and her colleagues, using surgically constructed chicken-quail chimeras (LeDourain et al., 1977), and Patterson, using in vitro model systems of primary embryonic neurons and clonal cell lines (Patterson and Chun, 1977; Patterson, 1978). These studies and others (Furshpan et al., 1976; Black, 1982; Landis and Keefe, 1983) have established the importance of the local environment and target tissue or factors produced by the target tissue in influencing neurotransmitter phenotype expression. In addition, they have argued strongly for an underlying mechanism by which alternative transmitter options are possible even after an initial decision has been made (Landis and Keefe, 1983; Black et al., 1984).

Neurons using classical neurotransmitters select a particular neurotransmitter phenotype by expressing the appropriate biosynthetic enzyme for transmitter production. Thus, for $\mathrm{ACh}$, a "cholinergic" neuron will transcribe and translate the gene for choline acetyltransferase (ChAT; EC 2.3.1.6). In addition, the genes for a number of other macromolecules involved in transmitter metabolism may also be expressed in the same cell or in target cells for the cholinergic neuron, such as the enzyme $\mathrm{AChE}$ (EC 3.1.1.7), which functions by hydrolyzing the transmitter, thus terminating its action. The appropriate neurotransmitter receptors must also be expressed on the target cells of cholinergic neurons.

Primary dissociated embryo cell cultures of Drosophila offer several attractive features for the study of ACh neurotransmitter phenotype expression during development and differentiation. In addition to being able to modify the culture environment, the genes for ChAT and AChE have been identified and genetically mapped in Drosophila, and several mutant alleles, including temperature-sensitive structural gene mutants, have been isolated (Hall and Kankel, 1976; Greenspan, 1980; Greenspan et al., 1980). In this paper we describe our initial studies characterizing the normal temporal expression of ChAT, AChE, and ${ }^{125} \mathrm{I}-\alpha$-bungarotoxin binding in Drosophila embryo cell cultures. We also report evidence that the normal programs of gene expression can be altered under a variety of experimental conditions involving manipulation of the culture environment. The combination of genetic definition and experimental accessibility of cultured cells should facilitate a description of both the genetic and epigenetic mechanisms regulating neurotransmitter phenotype selection.

\section{Materials and Methods}

Preparation of Drosophila embryo cultures. The following methods have been derived from the initial studies of Seecof and his collaborators and have been described in detail in Seecof (1980).

Egg collection and aging. Canton S Drosophila melanogaster flies were maintained in population cages at $25^{\circ} \mathrm{C}$ on a $12 \mathrm{hr} \mathrm{light/dark} \mathrm{cycle.}$ Eggs were collected on large $(100 \mathrm{~mm})$ petri plates containing standard corn meal medium supplemented with yeast for a 1 or $2 \mathrm{hr}$ period. In some experiments for which early timing was critical, a $30 \mathrm{~min}$ precollection was made. The eggs were allowed to age undisturbed on the collection plates for $3.5 \mathrm{hr}$ at $25^{\circ} \mathrm{C}$. This procedure assured that $>95 \%$ of the embryos had proceeded to the early gastrula stage. After aging, the embryos were harvested and cleaned by rinsing with distilled $\mathrm{H}_{2} \mathrm{O}$ on a nylon mesh sieve.

Preparation of embryo cultures. The embryos were dechorionated and sterilized by immersion for $2-3 \mathrm{~min}$ in a $1: 1$ solution of $95 \%$ ethanol and commercial Clorox. The embryos were mechanically dissociated by gentle homogenization using a Dounce homogenizer in modificd Schneider's Drosophila medium, supplemented with $18 \%$ heat-inactivated fetal calf serum and insulin $(200 \mathrm{ng} / \mathrm{ml})$, and collected by centrifugation. The cells were washed once in medium, pelleted, resuspended in medium, and counted in a hemocytometer. They were then plated in $35 \mathrm{~mm}$ tissue culture dishes at 0.8 or $1.6 \times 10^{6} \mathrm{cells} / \mathrm{ml}$ in 2 $\mathrm{ml}$ of medium. Approximately $10 \mathrm{~min}$ were required for embryo collection and $30-40 \mathrm{~min}$ to prepare cultures. The cells were allowed to attach to the bottom of the dish for 30-45 min, the media were replaced, and the cells cultured at $25^{\circ} \mathrm{C}$ in a dry-air incubator.

${ }^{3} \mathrm{H}-\mathrm{TdR}$ incorporation. For quantitative determinations of ${ }^{3} \mathrm{H}-\mathrm{TdR}$ incorporation, embryo cultures were pulse-labeled for $1 \mathrm{hr}$ periods with $2 \mu \mathrm{Ci}$ of ${ }^{3} \mathrm{H}$-TdR (methyl- ${ }^{3} \mathrm{H}-\mathrm{TdR}, 80 \mu \mathrm{Ci} / \mathrm{mmol}$; New England $\mathrm{Nu}-$ clear). Cells were harvested and the ${ }^{3} \mathrm{H}-\mathrm{TdR}$ incorporation and protein were determined as described in Yoshitake et al. (1982).

For radioautographic studies, cultures were pulse-labeled with $0.5-$ $2.0 \mu \mathrm{Ci}^{3} \mathrm{H}-\mathrm{TdR}$. To determine the percentage of cells undergoing DNA synthesis, during each labeling period, cultures were rinsed 3 times with modified Schneider's medium, fixed with $4 \%$ paraformaldehyde, and radioautographed for $24 \mathrm{hr}$ after coating the dish with a 1:1 dilution of Kodak NTB2 liquid emulsion in $\mathrm{H}_{2} \mathrm{O}$. Cells were viewed under brightfield optics to count labeled nuclei, and under phase-contrast optics to count the total number of cells. To determine which cell types were labeled during each pulsing period, replicate cultures were rinsed with fresh medium at the end of the labeling period and cultured in the absence of ${ }^{3} \mathrm{H}-\mathrm{TdR}$ until $18 \mathrm{hr}$ hefore fixation and radioautography, as described.

Immunocytochemistry. Anti-HRP antibody binding was determined by indirect immunofluorescence. The primary antibody was prepared in a rabbit and purified as described in Slemmon et al. (1980). Cells were cultured on gas-sterilized glass coverslips placed on the bottom of a $35 \mathrm{~mm}$ culture dish. The coverslips were rinsed in the dish with modified Schneider's saline, followed by PBS containing $1 \mathrm{mg} / \mathrm{ml}$ BSA and fixed for $30 \mathrm{~min}$ in $4 \%$ paraformaldehyde in PBS. Following 2 rinses with PBS-BSA, cells were incubated with primary antibody for $1 \mathrm{hr}$ in PBS at a concentration of $5 \mu \mathrm{g} \mathrm{IgG/ml}$. After rinsing with PBS-BSA, fluorescein- (Cappel; 200-fold dilution) or rhodamine-(Pel Freeze; 200fold dilution) labeled goat anti-rabbit antibody was added for $1 \mathrm{hr}$. The coverslips were rinsed with PBS, inverted onto a microscope slide on a drop of glycerol containing 1\% phenylenediamine (para), and examined under epi-illumination with an Olympus Vanox microscope.

Scanning electron microscopy. Cultures were grown on gas-sterilized glass coverslips and prepared for scanning electron microscopy using standard methods.

ChAT and AChE assays. The cells to be assayed for ChAT and AChE were gently washed 3 times with Schneider's saline (without $\mathrm{Ca}^{2+}$ and $\mathrm{Mg}^{2+}$ ), scraped off the dish with a Teflon policeman, and collected by centrifugation at $2000 \mathrm{rpm}$ for $5 \mathrm{~min}$ in an IEC refrigerated centrifuge $\left(4^{\circ} \mathrm{C}\right)$. Cells were resuspended in $200 \mu \mathrm{l}$ of PBS $\left(75 \mathrm{mM} \mathrm{PO}_{4}, 75 \mathrm{~mm}\right.$ $\mathrm{NaCl}, \mathrm{pH} 7.4$ ) containing $2 \%$ Triton $\mathrm{X}-100$ and homogenized in a small glass homogenizer. The samples were kept at $4^{\circ} \mathrm{C}$ for $30-60 \mathrm{~min}$ to solubilize the $\mathrm{AChE}$ activity, then stored at $-70^{\circ} \mathrm{C}$ until assay. ChAT 
Figure 1. Scanning electron micrograph of Drosophila embryo cells in culture at various developmental stages. $a$, Five-hour-old cells. Note that cells show little overt differentiation with at least 2 size classses present. (Solid arrow) points to a 8-10 $\mu \mathrm{m}$ cell; open arrow points to a $4-6 \mu \mathrm{m}$ cell. $b$, Ten-hourold cells. At this time most cells are smaller in diameter and tend to be present in clusters. The neuronal-type cells $(N)$ have processes at this stage that travel along the culture substrate. Myocyte (solid arrow) are present at this stage and appear flatter and more oval-shaped than the neurons. $c$, Twenty-four-hourold cells. At this time morphological differentiation is essentially complete. The myocytes have fused to form multinucleate myotubes (arrowhead), while the neuronal-type cells are present in 2 different arrangements: either 3-dimensional clusters of small, round cells (large curved arrow) or in a more isolated state (small curved arrow). In both arrangements the neuronal cells contain extensive varicose processes. (Open arrow) points to an axon connecting a neuron cluster to a myotube. Scale bar, $50 \mu \mathrm{m}$.
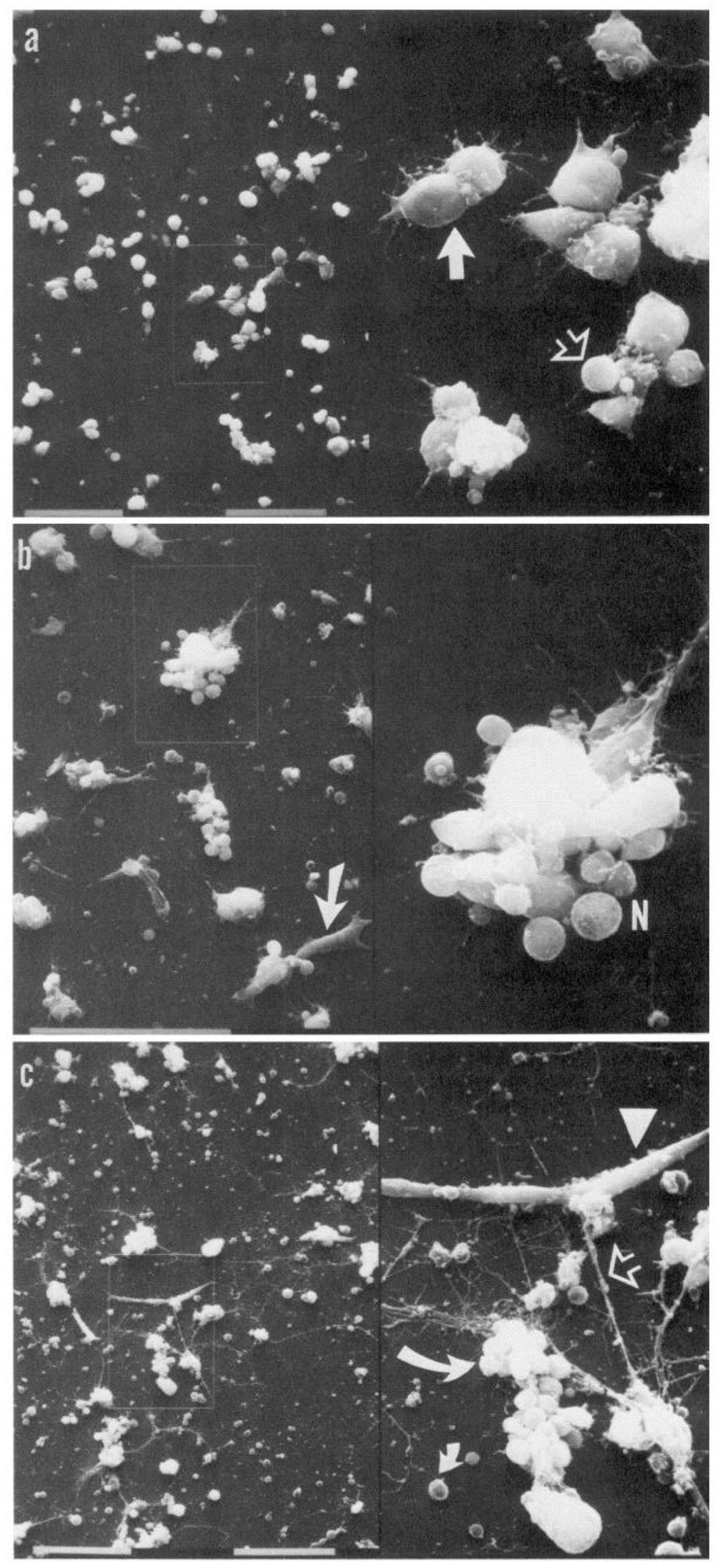


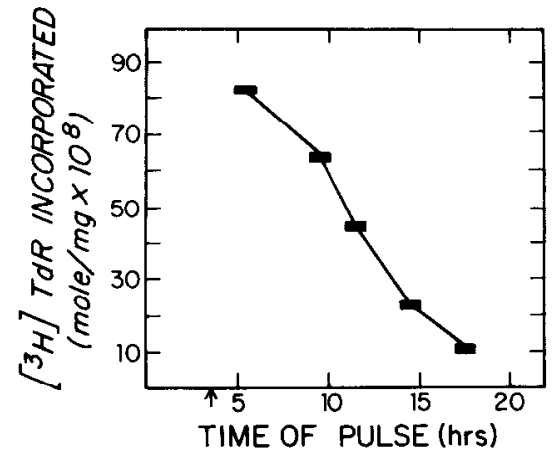

Figure 2. Incorporation of ${ }^{3} \mathrm{H}-\mathrm{TdR}$ into cultured cells of various developmental ages. Cells were pulse-labeled for $1 \mathrm{hr}$, as described, with $0.2-2 \mu \mathrm{Ci}$ of ${ }^{3} \mathrm{H}-\mathrm{TdR}$ at the times indicated. At the end of the pulsing period, cells were harvested and processed for ${ }^{3} \mathrm{H}-\mathrm{TdR}$ incorporation. The arrow indicates the time of culture initiation. Triplicate determinations showed a SE of $<10 \%$.

activity was determined by a modification (Dietz and Salvaterra, 1980) of the procedure of Fonnum (1975), using ${ }^{14} \mathrm{C}$-acetylCoA, and $\mathrm{AChE}$ was measured by the colorimetric procedure of Ellman et al. (1961), using acetylthiocholine as a substrate. All assays were performed under conditions of linearity for enzyme concentration and incubation time.

${ }^{125} I$ - $\alpha$-bungarotoxin binding. Cells were gently washed 3 times with $50 \mathrm{~mm}$ Tris, $50 \mathrm{~mm} \mathrm{NaCl}, 0.02 \% \mathrm{NaN}_{3}, \mathrm{pH} 7.4$ [Tris- $\mathrm{NaCl}^{-\mathrm{NaN}_{3}}$ (TNN)] containing $1 \mathrm{mg} / \mathrm{ml} \mathrm{BSA}$, and then scraped off the dish and collected by centrifugation. Cells were homogenized in $400 \mu$ l TNN plus BSA. The samples were stored at $-70^{\circ} \mathrm{C}$ until assay. The final ${ }^{125} \mathrm{I}-\alpha$-bungarotoxin concentration was $3 \times 10^{-9} \mathrm{M}$ and appeared to saturate $>90 \%$ of the specific binding sites following $90 \mathrm{~min}$ incubation at room temperature. Toxin-binding assay details are described in Salvaterra and Foders (1979).

Protein assay. One replicate culture for each experimental group was used for protein assay, following the method of Lowry et al. (1951). The cultures were gently washed 3 times with Schneider's saline (with $\mathrm{Ca}^{2+}$ and $\mathrm{Mg}^{2+}$ ) and dissolved in $1 \mathrm{ml}$ of $1 \mathrm{~N} \mathrm{NaOH}$ for $2-3 \mathrm{hr}$ at $25^{\circ} \mathrm{C}$.

AChE histochemistry. AChE activity was localized histochemically by the acetylthiolcholine procedure of Karnovsky and Roots (1964). Cells were grown on gas-sterilized glass coverslips and fixed for $30 \mathrm{~min}$ by immersion in 4\% paraformaldehyde in PBS. Appropriate pharmacological controls included staining cells in the presence of $1 \times 10^{-6} \mathrm{M}$ 1,5-bis(4-allyldimethylammoniumphenyl)-pentane-3-onedibromide (BW284C51), a specific AChE inhibitor, or iso-tetraisopropylpyrophosphoramide (OMPA), a nonspecific esterase inhibitor, following a 30 min preincubation with the inhibitors.

Experimental procedure for drug additions. After cells were plated out at a cell concentration of $1.6 \times 10^{6} \mathrm{cells} / \mathrm{ml}$ and allowed to attach to the plate for $30-45 \mathrm{~min}$, the medium was replaced with fresh culture medium. The drugs to be tested were dissolved in modified Schneider's saline and added directly to the cell cultures in volumes of 20 or 200 $\mu 1$. The cultures were incubated for the appropriate period of time at $25^{\circ} \mathrm{C}$ and then assayed for ChAT, AChE, or protein. Replicate control cultures were treated the same way, with the addition of modified Schneider's saline.

Experimental procedure for the preparation and testing of conditioned media. Embryo cultures were prepared and maintained for 1-7 d. The media were harvested, clarified by centrifugation at $3000 \mathrm{rpm}$ for 10 min, and aliquots stored at $-70^{\circ} \mathrm{C}$. Conditioned media were mixed with fresh media and added in the amounts indicated to freshly prepared embryo cultures $\left(1.6 \times 10^{6} \mathrm{cells} / \mathrm{ml}\right)$ following the attachment period. The cells were grown for 1 or $2 \mathrm{~d}$ in the presence of conditioned media.

\section{Results}

\section{General morphology}

As originally noted by Seecof and his collaborators (Seecof et al., 1973a-c; Gerson et al., 1976) and Shields and Sang (1970; Shields et al., 1975), dissociated Drosophila melanogaster gastrula-stage embryonic cells grow and rapidly differentiate in vitro into several morphological cell types. Figure 1 shows the ap-

\begin{tabular}{|c|c|c|c|}
\hline \multirow{2}{*}{$\begin{array}{l}\text { Develop- } \\
\text { mental } \\
\text { time } \\
(\mathrm{hr})^{a} \\
5\end{array}$} & \multicolumn{2}{|c|}{$\begin{array}{l}\text { HRP-positive } \\
\begin{array}{ll}\text { cells }{ }^{b} & \text { HRP-positive cell } \\
\% & \text { diameter }(\mu \mathrm{m})\end{array}\end{array}$} & \multirow{2}{*}{$\begin{array}{l}\text { HRP-positive } \\
\text { process } \\
\text { length }{ }^{d} \\
(\mu \mathrm{m})\end{array}$} \\
\hline & 4.8 & $6 \pm 2 \quad(60)$ & \\
\hline 8 & 15.2 & $6 \pm 1.9(100)$ & $8.5 \pm 4$ \\
\hline 11 & 44.9 & $5.5 \pm 1.4(200)$ & $17 \pm 7.5$ \\
\hline 17 & 70.9 & $4.8 \pm 1.2(200)$ & $35.6 \pm 15$ \\
\hline
\end{tabular}

a Times refer to hours postoviposition.

${ }^{b}$ A total culture area of $5.8 \times 10^{5} \mu \mathrm{m}^{2}$, containing at least 1000 cells, was counted for all times.

Values represent means \pm SD ( $n$ in parentheses). Only cells with clearly defined diameters were included.

${ }^{d}$ Values represent means \pm SD of longest dimension for at least 40 processes extending from individual cells or cell clusters.

pearance of cultured cells in a scanning EM at various times, while the appcarance of cells in phase contrast is shown in Figurc 5. All times indicated refer to hours postoviposition. Initially and at times of up to about $7 \mathrm{hr}(3.5 \mathrm{hr}$ in culture $)$, most cells exhibit no overt cell type-specific morphology. They appear as round, undifferentiated cells of at least 2 size classes: larger cells, with a diameter of approximately $8-10 \mu \mathrm{M}$, and smaller cells between 4 and $6 \mu \mathrm{M}$ (see Figs. $1 a$ and $5 a$ ). The cells appear well dispersed, with only a few clusters containing 3-5 small, round cells. Few cell processes are visible at these early culture stages. After 9 or $10 \mathrm{hr}$, some differentiated cell types are easily recognizable under phase contrast (Fig. 5c). Many small (4-5 $\mu \mathrm{M}$ ), round phase-bright cells are now arranged in clusters and contain fine cell processes characteristic of neurons (Figs. $1 b$ and $5 c$ ). This is the major cell type present in the cultures at this stage. Other, flatter, ovoid-shaped cells having the appearance of myocytes are also present (see Fig. $1 b$ ). By 17 or $18 \mathrm{hr}$, most of the myocytes have fused to form easily recognizable multinucleate myotubes containing 3-5 nuclei (range, 2-15) (Fig. 1c). The neuronal-type cells are present primarily in clusters of small, round phase-bright cells (Fig. $4 e$ ) and have extensive process development at this stage. At this plating density, bundles of fibers usually contact neighboring neuronal clusters (Fig. 1c). Often larger-phase granular cells appear associated with the neuronal-type clusters. Individual or paired small, round phasebright neuronal-type cells with processes can also be seen at this stage of culture (Figs. $1 c$ and $4 e$ ). The morphological appearance of the neuronal-type cells and myotubes does not change appreciably after $18-24 \mathrm{hr}$, and these 2 cell types make up the bulk of the cells $(>80 \%)$ present at $24 \mathrm{hr}$. At least 2 other cell types have been described at later culture times (Shields and Sang, 1970; Cross and Sang, 1978a,b); one is probably an adipocyte and the other a chitin-secreting cell.

It is evident from Figure 1 that the myotubes are long flat cells, while the neuronal clusters with the associated non-neuronal cells are organized in a 3-dimensional array, with the cell processes running along the surface of the coverslip. The surface of the neuronal-type cells appears to be smooth, while the processes have a varicose appearance. More isolated neuronal-type cells also appear to have a smooth, round surface.

\section{${ }^{3} H-T d R$ incorporation}

Since the number of cells in culture increases rapidly between 3.5 and $18 \mathrm{hr}$, and differentiated cell types are evident at later 

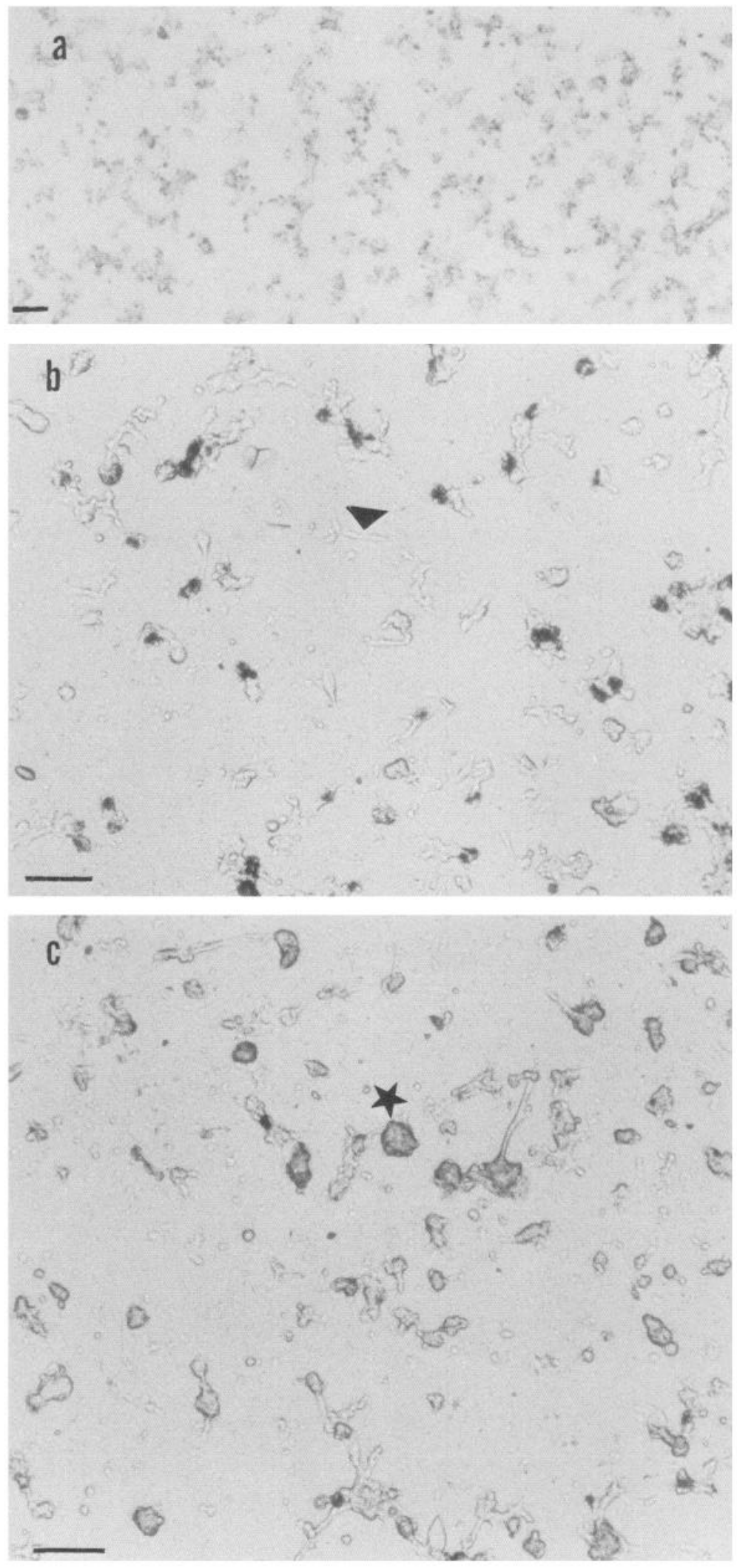

Figure 3. Autoradiographs of ${ }^{3} \mathrm{H}-\mathrm{TdR}$ incorporation into cells of various developmental ages. $a$, Six-hour-old cells pulse-labeled between 5 and $6 \mathrm{hr}$ with $2 \mu \mathrm{Ci}{ }^{3} \mathrm{H}-\mathrm{TdR}$. Nearly all cells incorporate label over their nuclei at this stage. $b$, Twelve-hour-old cells pulselabeled between 11 and $12 \mathrm{hr}$. Approximately $60 \%$ of all cells are labeled; however, no myocytes (arrowhead) are labeled after a pulse between 8 and 9 hr. $c$, Eighteen-hour cells pulse-labeled between 17 and $18 \mathrm{hr}$. Only about $10 \%$ of the cells are labeled at this stage and they are mostly the neuronal-type cells present in clusters (star). The myotubes are not labeled at this stage. Scale bar, $20 \mu \mathrm{m}$. times, the original cells must contain mitotically competent neuronal and muscle cell precursors. The quantitative incorporation of ${ }^{3} \mathrm{H}$-TdR following 1-hr-long pulse-labeling periods is shown in Figure 2. The rate of ${ }^{3} \mathrm{H}-\mathrm{TdR}$ incorporation during early pulsing periods is high and decreases rapidly during later pulse times. Table 1 summarizes the percentage of total cells labeied as a function of pulse time. When the cultures are pulse-labeled at later times, the percentage of labeled cells decreases and the various cell types cease to incorporate label after different pulse times (Fig. 3). Essentially all cell types are labeled when the ${ }^{3} \mathrm{H}$ TdR pulse is applied between 5 and $6 \mathrm{hr}$. Examination of the cultures at $18 \mathrm{hr}$ following the 5-6 hr pulse shows incorporation 


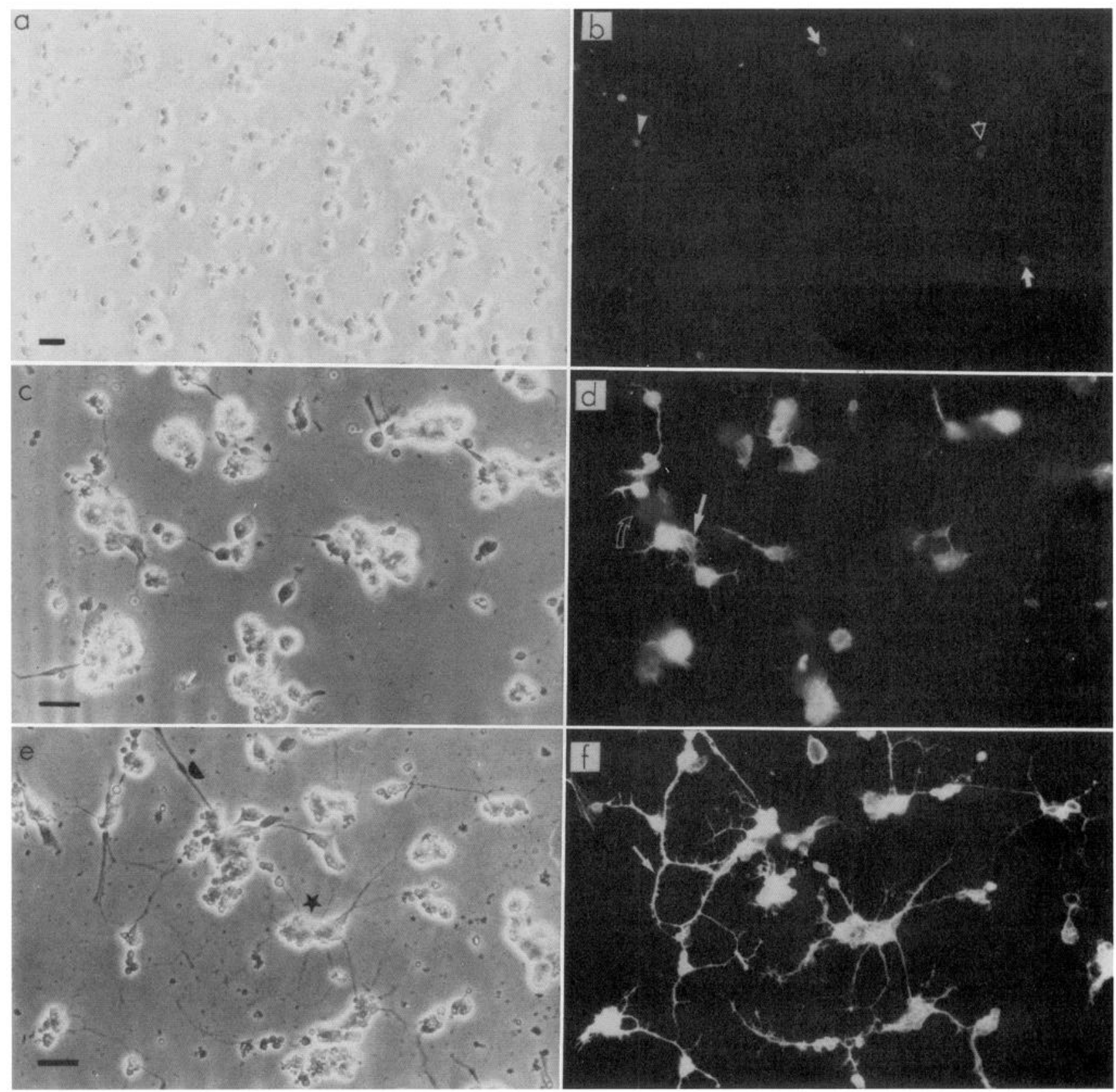

Figure 4. Staining of cultured cells at various developmental ages with anti-HRP antibody. $a$, Phase-contrast view of 5-hr-old cells. $b$, Fluorescence view of the same field as in $a$. Either single large cells (arrows), smaller cells in groups (arrowhead), or attached large and small round cells (open arrowhead) are stained at this stage. $c$, Phase-contrast and $d$, fluorescence of the same field of 10-hr-old cells. At this stage some large bottle-shaped cells (arrow) are positive, with all of the small, round neuronal-type cells either in clusters or more isolated showing positive staining. Open arrow indicates a non-neuronal (nonstaining) cell. $e$, Phase-contrast and $f$, fluorescence view of the same field of 18 -hr-old cells. At this time, morphological differentiation is essentially complete for the myotubes (semicircle) and the neuronal-type cells (star). Only the neuronal-type cells and their processes are stained. Note also the process growth along the surface of the myotubes (arrow). The large bright patches of fluorescence are neuronal clusters that are out of the plane of focus at this magnification $(400 \times)$. Scale bar, $20 \mu \mathrm{m}$.

of label into all cell types; however, the relative intensity of radioautographic grain distribution is variable, perhaps reflecting different numbers of cell divisions. Figure 3 also illustrates the incorporation of label into some of the small, round clustered and individual neuronal-type cells during all pulsing intervals up to and including $18 \mathrm{hr}$. In contrast, no myocytes or myotubes incorporate label after the 8-9 $\mathrm{hr}$ pulse period, which confirms the observations of Seecof and Dewhurst (1976) of a more restricted myoblast division time. These data agree well with the description of ${ }^{3} \mathrm{H}-\mathrm{TdR}$ incorporation into intact embryos; i.e., the neuronal precursors have an extended period of cell division, while muscle cell precursors have a more restricted mitotic period (Campos-Ortega, 1982).

\section{Expression of HRP-like antigen}

The cultured embryo cells express an antigen that can be recognized by antibodies to HRP. Figure 4 shows the in vitro expression of the HRP-like antigen as a function of time. The antigen is present at all times examined. However, the morphology of positive cells undergoes considerable change. Ini- 

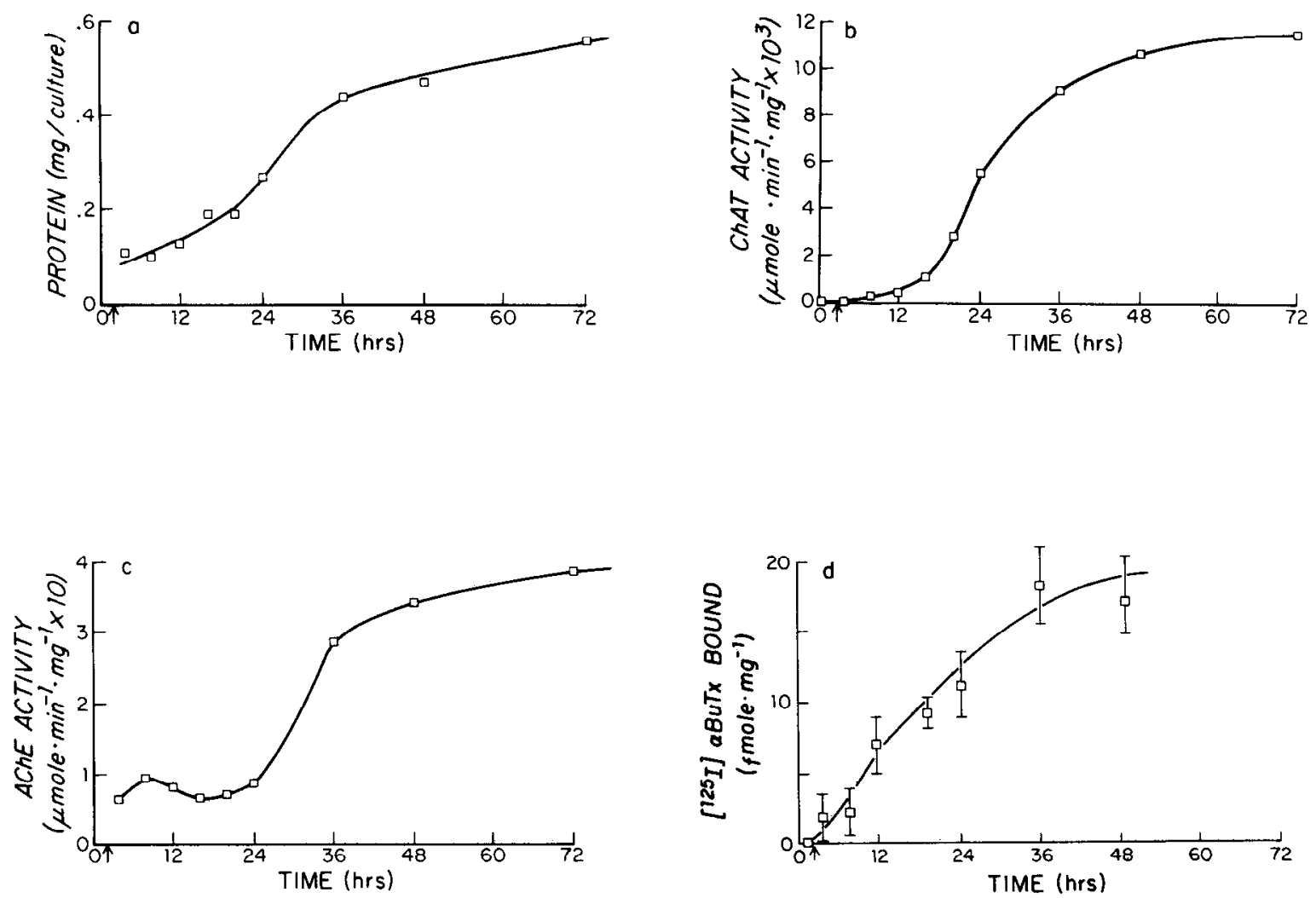

Figure 5. Normal in vitro expression of $a$, protein, $b$, ChAT activity, $c$, AChE activity, and $d$, ${ }^{125}$ I- $\alpha$-bungarotoxin binding in Drosophila dissociated embryo cell cultures. Eggs were collected for 1-2 hr and put into culture at $3.5 \mathrm{hr}$ (arrows) as described. Three of 4 plates were pooled and assayed in triplicate at the times indicated. The SEM is indicated for toxin-binding measurements; all other parameters had a SEM less than the height of the symbols.

tially, at least 2 size classes of cells are positive, as illustrated in Figure $4 b$. The larger cells have a diameter of approximately $8 \mu \mathrm{M}$ and often appear to have small, short $(<1 \mu \mathrm{m})$ hairlike processes around their periphery. These processes are not visible in phase contrast at this stage. The smaller cells are often in clusters of 2 or 3 cells, with a diameter of 4-5 $\mu \mathrm{m}$. They have the smooth, round phase-bright shape characteristic of neuronal-type cell bodies present at later stages; however these $5 \mathrm{hr}$ cells have no processes. Often a larger and smaller HRP-positive cell appear to be attached to each other, resembling the asymmetric division pattern described for ventral neuroblasts (Poulson, 1950; Hartenstein and Campos-Ortega, 1984). At approxiately $10 \mathrm{hr}$, when several different cell types are recognizable by phase contrast (Fig. $4 c$ ), the small, round cells, either singly or more often in clusters, are HRP-positive (Fig. $4 d$ ). In addition, their processes are quite elaborate and are beginning to contact adjacent clusters. We also see large bottle-shaped cells, which are weakly positive for HRP at this culture stage (Fig. $4 d$ ). By $18 \mathrm{hr}$, the major HRP-positive cells in the culture are of the clustered neuronal type, with elaborate process development (Fig. 4f). Other positive cells are also present, either singly or in pairs, with long fine processes. No myotubes or large phase-granular cells are stained by the antibody. Most adjacent clusters appear to be contacting one another with their processes. The processes emanating from the clustered neuronal cells often appear thick and may represent bundles of individual fibers. They occasionally course along the surface of a myotube before continuing onto another cluster of neurons (Fig. 4e). In other, less frequent, cases, the processes from nonclustered HRP-positive cells terminate upon contacting a myotube. Quantitativc data concerning HRP staining as a function of cell age are summarized in Table 2.

We have also cultured cells in the presence of $1 \mathrm{mg} / \mathrm{ml}$ of anti-HRP antibody - a concentration that should have saturated any antigen on the cell surface-to see if normal morphological differentiation was perturbed. No effect on the morphological appearance of the cultures was observed after $24 \mathrm{hr}$ in the presence of anti-HRP antibody.

Normal in vitro development of $C h A T, A C h E$ and ${ }_{125}$ I- $\alpha$-bungarotoxin binding

As was initially demonstrated by Dewhurst and Seecof (1975; 1979), primary dissociated cultures of gastrula-stage embryo cells acquire the ability to synthesize and hydrolyze $\mathrm{ACh}$. We have extended these original observations to include additional, i.e., both longer and shorter culture times, and have also measured levels of ${ }^{125} I-\alpha$-bungarotoxin binding.

Figure 5 shows the results of the temporal expression of $\mathrm{ACh}$ metabolizing enzymes and ${ }^{125} \mathrm{I}$ - $\alpha$-bungarotoxin binding sites under normal culture conditions. Values reported at times of less than $3.5 \mathrm{hr}$ were determined in dechorionated, dissociated embryos that were not cultured. As can be seen in Figure $5 a$, protein undergoes a smooth, approximatcly lincar increase for about 48 $\mathrm{hr}$, and then levels off. Expression of ChAT activity appears to be distinguished by several phases (Fig. $5 b$ ). Initially no ChAT is detectable either in embryos or in the earliest culture assay 

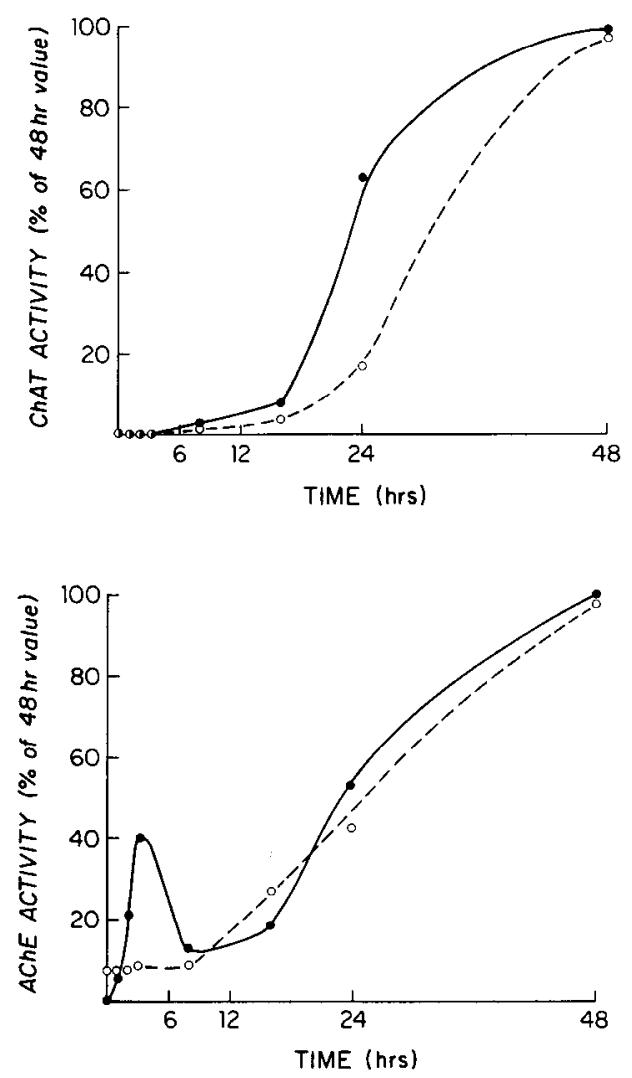

Figure 6. Comparison of the developmental time course for ChAT and $\mathrm{AChE}$ activity in culture $(-)$ and in vivo (-- ). The specific activity of ChAT at $48 \mathrm{hr}$ was $9.93 \times 10^{-3}$ and $3.0 \times 10^{-3} \mu \mathrm{mol} \mathrm{min}^{-1}$ $\mathrm{mg}^{-1}$ for the cultures and in vivo, respectively, and AChE activity was 0.32 and $0.25 \mu \mathrm{mol} \mathrm{min}^{-1} \mathrm{mg}^{-1}$ for cultures and in vivo.

time. After $5 \mathrm{hr}$, a small but significant amount of enzyme can be detected and the activity increases slowly until about $12 \mathrm{hr}$. After $12 \mathrm{hr}$ there is a rapid logarithmic increase in ChAT activity, which plateaus at around $36-48 \mathrm{hr}$.

In contrast to ChAT activity, AChE activity is initially detectable in the embryos and at all culture time points (Fig. $5 c$ ). In experiments using specific and nonspecific esterase inhibitors, we have determined that 3-hr-old embryos contain only $15 \%$ BW284C51-inhibitable esterase activity. Thus the majority of activity measured at the earlier times $(<5 \mathrm{hr})$ is most likely nonspecific esterase. After $18 \mathrm{hr}$, however, $>90 \%$ of the activity can be inhibited by $1 \times 10^{-6}$ M BW284C51 but not by $1 \times$ $10^{-6} \mathrm{M}$ iso-OMPA, a nonspecific esterase inhibitor, and therefore represents "true" AChE activity. The developmental time course for AChE expression shown in Figure $5 c$ is similar to that of ChAT expression in that there is a period of low-level esterase expression followed by a logarithmically increasing period. The low-level expression appears before ChAT activity, but the logarithmically increasing period for AChE occurs at a somewhat later time than ChAT.

${ }^{125} \mathrm{I}-\alpha$-bungarotoxin binding is shown in Figure $5 d$. Initially, ${ }^{125} \mathrm{I}$ - $\alpha$-bungarotoxin can be detected at $4.5 \mathrm{hr}$ and it increases linearly until about $24 \mathrm{hr}$. The levels of ${ }^{125} \mathrm{I}-\alpha$-bungarotoxin proved more variable than those of either ChAT or AChE, possibly because of the low levels of toxin-binding sites.

The in vitro expression pattern of ChAT and $\mathrm{AChE}$ remains faithful to that seen in vivo with respect to both the temporal

\begin{tabular}{lll}
\hline $\begin{array}{l}\text { Table 2. } \\
\text { Tim-TdR incorporation into cultured }\end{array}$ \\
\begin{tabular}{lll}
$\begin{array}{l}\text { Time of pulse } \\
\text { (hr) }\end{array}$ & $\begin{array}{l}\text { Labeled cells/total } \\
\text { cells counted }\end{array}$ & $\begin{array}{l}\text { Cells labeled } \\
(\%)\end{array}$ \\
\hline $5-6$ & $345 / 361$ & 95.6 \\
$8-9$ & $249 / 258$ & 96.5 \\
$11-12$ & $456 / 771$ & 59.1 \\
$14-15$ & $178 / 803$ & 22.2 \\
$18-19$ & $105 / 938$ & 11.2
\end{tabular}
\end{tabular}

" Duplicate cultures were pulse-labeled for $1 \mathrm{hr}$ with $2 \mu \mathrm{Ci}$ of ${ }^{3} \mathrm{H}$ - $\mathrm{IdK}$ at the indicated times. Cultures were washed and processed for radioautography, as described in Materials and Methods. Positively labeled cells and total cells were counted for 5 representative culture fields, al a total magnification of $200 \times$.

order of appearance and the time it takes to reach maximum levels. Figure 6 shows ChAT and AChE levels in culture, compared with the levels in intact organisms. It should be noted that both ChAT and AChE reach a higher specific activity in culturc, than in intact organisms, which probably reflects the simplified cell types present in culture (i.e., less protein) compared to those in intact organisms.

The AChE histochemical staining pattern is shown in Figure 7. The staining is restricted to only some of the neuronal cells present in clusters. Myotubes and larger phase-granular cells are negative. Not all clusters of small, round cells are stained and not all cells within a cluster are stained. We estimate that about $40 \%$ of the clusters in a culture are AChE-positive. The staining is evident in both the cell bodies and processes of positive cells. BW284C51 blocks all staining at a concentration of $1 \times 10^{-6}$ $M$, while iso-OMPA has no effect.

\section{Effects of manipulating the culture environment on ChAT and $A C h E$ expression}

Two important questions raised by numerous studies of transmitter phenotype expression in vertebrates concern the relative importance of contributions by environmental factors and/or use-dependent feedback mechanisms. It has been amply demonstrated both in vivo and in vitro that the transmitter options available to a neuron can be specified and maintained by the position of the neuron within the developing embryo, as well as by factors produced by normal and/or abnormal target tissue (LeDourain et al., 1977; Patterson, 1978; Landis and Keefe, 1983). We have thus attempted to perturb the normal expression patterns for ChAT and AChE in our embryonic gastrula-stage cell cultures by manipulating the culture environment.

For our initial studies we chose drugs that are known in other systems to exert an effect on cholinergic cells. Thus, $d$-tubocurarine (dTC) and scopolamine (SCOP) are generally regarded as nicotinic and muscarinic AChR blockers, while carbamylcholine (CARB) is a nonhydrolyzable ACh analog and BW284C51 is a potent and specific AChE inhibitor. Figure 8 shows the concentration-dependent effects of culturing cells for $48 \mathrm{hr}$ in the presence of these cholinoactive agents. Both ChAT and AChE activity are decreased under these conditions; however, ChAT activity appears to undergo a greater reduction than $\mathrm{AChE}$. The effects of all drugs are due to chronic exposure of the cultured cells, rather than to acute inhibitory effects (with the exception of the BW284C51 effect on AChE activity), since the enzyme activity in control experiments, where the indicated concentration of drug was added immediately before washing and harvesting the cells, did not differ from that in cultures where no 


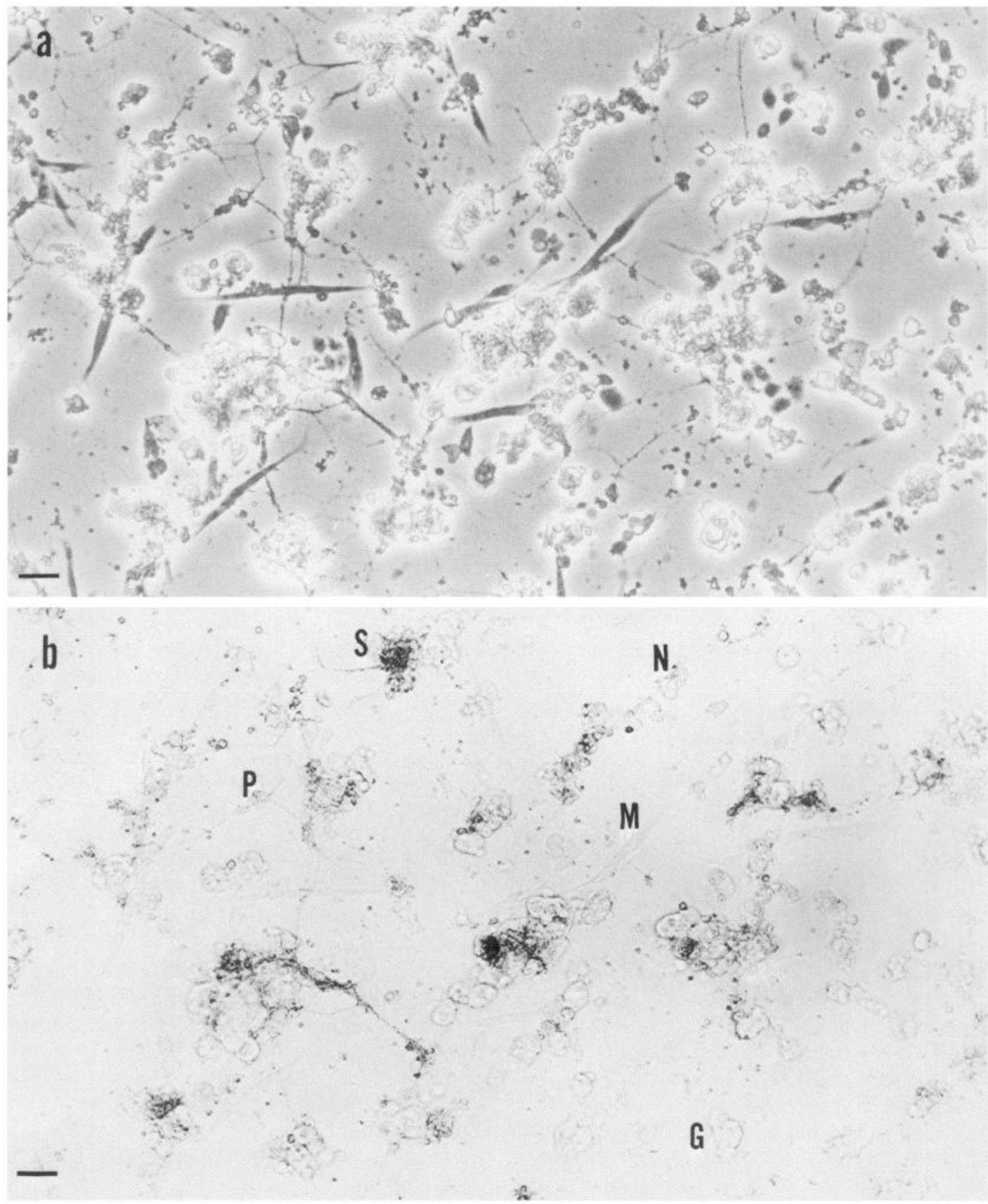

Figure 7. Histochemical stain for AChE. A $48 \mathrm{hr}$ culture was fixed in paraformaldehyde and stained for AChE activity as described. $a$, Phasecontrast micrograph showing the various cell types present in the culture at this stage. $b$, Bright-field photomicrograph of the same field shown in a. Myotubes $(M)$ and large phase-granular cells $(G)$ are unstained. In neuronal clusters, some show staining in all cells $(S)$, while others show no staining $(N)$ or only partial staining $(P)$. Scale bar, $20 \mu \mathrm{m}$.

drug was added. In addition, none of the drugs altered protein concentration, lactate dehydrogenase activity, or the normal morphological appearance of the cultures, thus ruling out a general cell-toxic effect for these agents.

It was of interest to see if these cholinoactive drug effects were more apparent during the earlier phase of logarithmically increasing enzyme activity or at later culture times, when enzyme activities begin to reach their maximum levels. Figure 9 shows that the decreased ChAT activity is clearly more dramatic after $48 \mathrm{hr}$. In a number of experiments in which the drugs were present only during the $24-48 \mathrm{hr}$ period, more normal enzyme activity was observed (data not shown). Likewise, when drugs were added for only the first $24 \mathrm{hr}$ period, normal enzyme activity was observed after $48 \mathrm{hr}$. It thus seems that there may be a critical developmental time of exposure to the drugs, as well as a necessity to maintain the cultures in the presence of drugs, in order to see a decrease in enzyme expression.

Although the physiology of Drosophila cholinergic receptors is not known, it is likely, on the basis of binding studies, that they contain both nicotinic and muscarinic receptor types (Dudai and Ben-Barak, 1977; Salvaterra and Foders, 1979). The decrease in ChAT activity seen after exposing cultures to both 


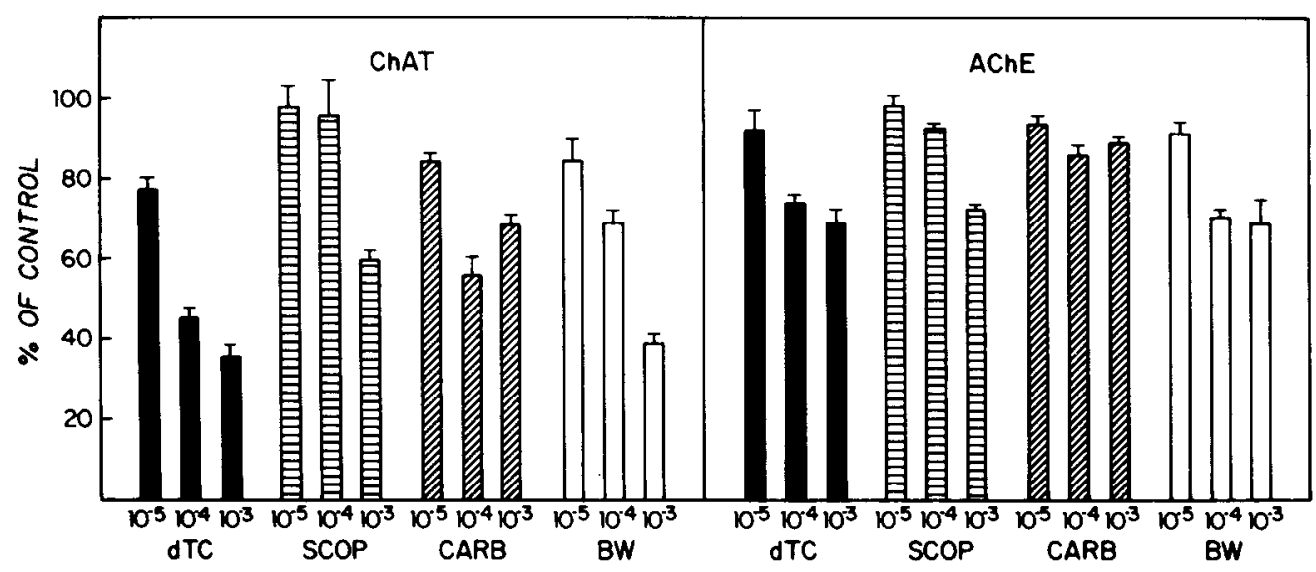

Figure 8. The dose-response effect of cholinergic drugs on the expression of ChAT and AChE in $48 \mathrm{hr}$ embryo cultures. Drugs were added to fresh embryo cultures in the concentrations indicated following a $30 \mathrm{~min}$ attachment period. Values represent the means \pm SEM for triplicate assays. Drugs: $d T C, d$-tubocurarine; $S C O P$, scopolamine, $C A R B$ carbamylcholine; BW284C51.
dTC, a nicotinic blocker, and SCOP, a muscarinic ligand, is not appreciably greater than when either drug is present alone (Fig. 9); thus the effects of blocking both subtypes of AChR do not seem to be additive with respect to decreased ChAT levels.

The most dramatic effect we have observed on the normal in vitro expression pattern of $\mathrm{ChAT}$ and $\mathrm{AChE}$ took place after culturing the cells in the presence of conditioned medium taken from older cultures. Figure 10 shows a dose-dependent decrease in the expression of both enzymes after 24 and $48 \mathrm{hr}$ of culture in medium collected from 7 -d-old embryo cultures. The expression of ChAT is affected to a greater degree than that of AChE. AChE activity also seems to decrease significantly more after $48 \mathrm{hr}$ of culture in conditioned medium as compared to 24hr-cultures. The effects of conditioned medium seem to be relatively specific for the expression of ChAT and AChE, since we have observed no significant change in the appearance of the cells, lactate dehydrogenase (LDH) activity, or protein levels at concentrations of up to $15 \%$ conditioned medium. At $20 \%$ conditioned medium, however, some toxic effects may be present, since the protein levels attained by the cultures after $48 \mathrm{hr}$ are reduced by about $30 \%$.

The decreased expression of ChAT and AChE activity can be detected in medium conditioned for only $24 \mathrm{hr}$, and seems to attain maximum effectiveness after $48 \mathrm{hr}$, as is shown in Figurc 11. Also, the responsible factor(s) must accumulate during a 48 hr culture period, since media harvested from cells between 24 and $48 \mathrm{hr}$ have an intermediate effect compared to 24 and 48 hr media (Fig. 11). The ability of conditioned medium to decrease cholinergic enzyme activity is stable when medium is stored at $-90^{\circ} \mathrm{C}$ for at least several months. We have also tested media conditioned from Oregon $\mathrm{R}$ and Schneider's Drosophila cell lines (which do not express any ChAT) and have not observed any decreased ChAT or AChE expression.

\section{Discussion}

Early gastrula-stage Drosophila embryo cells, which divide in culture, incorporate ${ }^{3} \mathrm{H}-\mathrm{TdR}$ and differentiate into a relatively simplified collection of recognizable cell types, including neurons. The neuronal cells, as well as their precursors, express a molecule characteristic of embryonic and mature Drosophila neurons in vivo (Jan and Jan, 1982).

These neuronal-type cells are present in at least 2 distinct arrangements: closely associated with one another in clusters of small, round cells or in a more isolated state ( $1-4$ cells). The clustered cells are reminiscent of the ventral nervous system ganglion cell arrangement described for in vivo nervous system development (Hartenstein and Campos-Ortega, 1984). In vivo, each ganglion cell in the ventral nervous system is thought to arisc from a single large neuroblast that has undergone a series of 9 unequal cell divisions, followed by 1 terminal division of

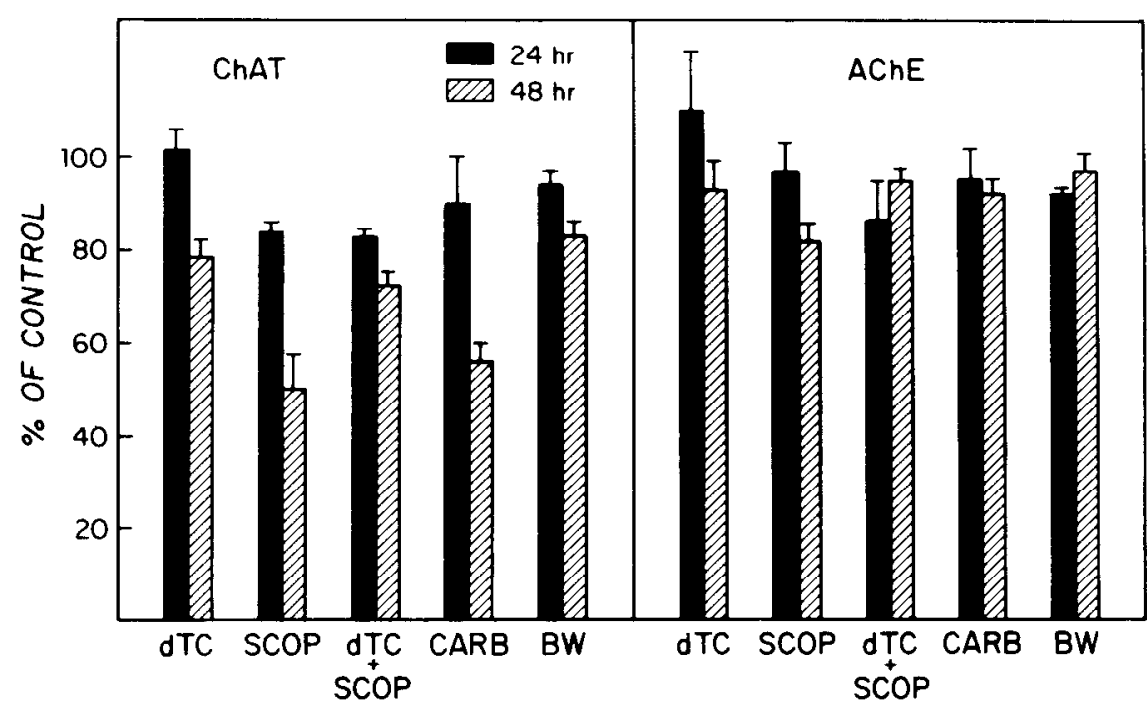

Figure 9. Time dependence of decreased enzyme expression following exposure to cholinergic drugs. All drugs were added to fresh cultures, following a $30 \mathrm{~min}$ cell attachment period, at a concentration of $1 \times 10^{-5} \mathrm{M}$ except CARB $(1 \times 10 \mathrm{E}-4 \mathrm{~m})$. Cells were cultured for up to 24 or $48 \mathrm{hr}$, harvested, and assayed for enzyme activity as described. Values represent the mean of triplicate assays \pm SEM. Abbreviations, as in legend to Figure 8. $d T C+S C O P$ indicates that the 2 drugs were added together. 


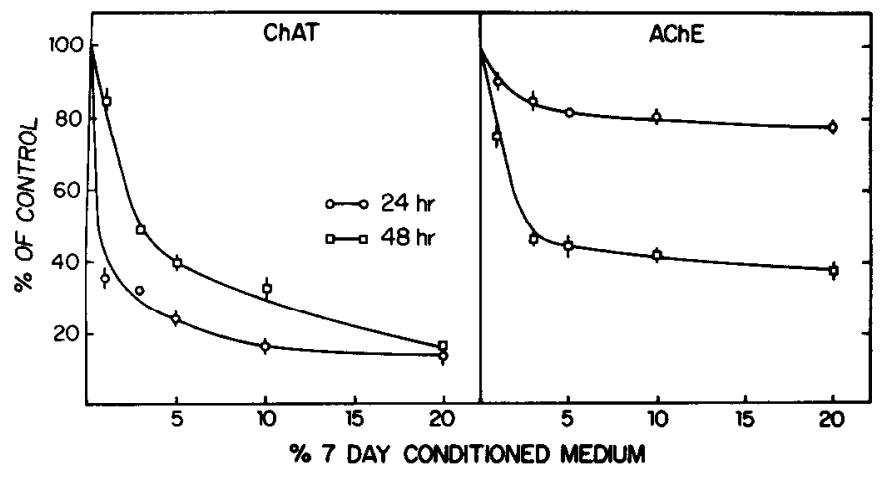

Figure 10. Concentration dependence of conditioned medium in reducing $\mathrm{ChAT}$ and $\mathrm{AChE}$ activity. Conditioned medium was harvested from 7-d-old embryo cell cultures mixed with fresh medium at the concentrations indicated and used to prepare fresh embryo cultures. After 24 or $48 \mathrm{hr}$, the cells were harvested and assayed in triplicate. Values represent the mean \pm SEM.

the daughter cells. This pattern of cell division results in 18 cell neuron clusters that are thus clonally related. It is difficult to count precisely the number of cells present in an in vitro cluster, owing to its 3-dimensional arrangement. However, the size of most of the clusters we observe can be calculated as containing 16-20 cells and thus may also be descended from a single neuroblast and be clonally related. The more isolated neuronal-type cells could perhaps arise from midline precursor cells or ganglion mother cells, which have fewer rounds of cell division in vivo (Poulson, 1950; Hartenstein and Campos-Ortega, 1984). Furst and Mahowald (1985b) have recently analyzed the in vitro cell division patterns of Drosophila neuroblasts and present direct evidence for the clonal nature of the cells in neuron clusters; they have also noted a relationship between initial neuroblast size and the resulting number of neurons in a cluster.

No functional significance has yet been ascribed to the HRPlike antigen expressed by insect neurons, and we have observed no perturbation of the in vitro morphological differentiation when cells are cultured in the presence of a large excess of antiHRP antibody. It is thus likely that at least the antigenic determinant(s) recognized by the antibody do not have important regulatory role(s) for neuronal differentiation. In the original article describing the in vivo appearance of HRP-like antigen (Jan and Jan, 1982), no neuroblast cells were positive. In cultured cells, we have observed positive staining of large "neuroblast-like" cells at early culture times $(5 \mathrm{hr})$, when no neurons are present. Since nearly all cells are capable of incorporating ${ }^{3} \mathrm{H}-\mathrm{TdR}$ at this stage, it is likely that we can use the antibody to identify a population of mitotically competent neuronal precursor cells. It may be that we are able to observe HRP-positive "neuroblast-like" cells at this early stage, in contrast to in vivo, because the antigenic sites are expressed at higher concentrations or in a less restricted conformation in vitro. These large "neuroblast-like" HRP-positive cells may be equivalent to the class III cells recently isolated by Furst and Mahowald (1985a), and which were observed to differentiate into clustered neurons in vitro.

Fluorescent anti-HRP antibody staining also provides an excellent means of observing the fine process growth at early culture stages, when the processes are not clearly visible by phasecontrast microscopy. We can clearly observe the first contacts of adjacent neuronal clusters at around $10 \mathrm{hr}$ in our cultures.

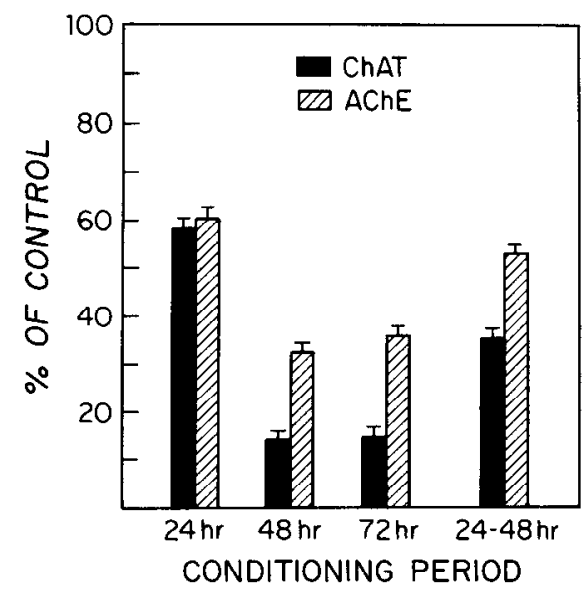

Figure 11. Effect of the conditioning period on the ability of conditioned medium to reduce ChAT and AChE activity. Medium was conditioned by embryo cultures for the times indicated, harvested, and added to fresh cultures at a concentration of $10 \%$. Cells were grown to $48 \mathrm{hr}$, harvested, and assayed in triplicate. Values represent the mean \pm SEM.

This is also about the time when synaptogenesis is thought to begin in intact embryos (Campos-Ortega, 1982).

In vivo Drosophila neuroblasts that form the ventral nervous system have recently been described as segregating from other ectodermal derivatives and producing ganglion cells in at least 3 overlapping phases (Hartenstein and Campos-Ortega, 1984). It is also known that imaginal neuroblasts are produced during embryogenesis (Campos-Ortega, 1982) and that other neurons arise from midline precursor cells (Thomas et al., 1984). We have no way at present of identifying the precise origin of our neuronal precursor cells; however, we do see an extended pattern of neuronal DNA synthesis in vitro. Some neuronal clusters can be labeled with ${ }^{3} \mathrm{H}$-TdR when the cells are pulsed as late as at $17-18 \mathrm{hr}$.

One curious feature about the in vitro development of these gastrula-stage cells is the relatively simplified collection of cell types that differentiate. This may be due to a number of factors, including selective cell survival under culture conditions. In this regard, it should be mentioned that the majority of embryo cells plated survive. Also, the mitotic activity appears rather high initially, and we don't observe any massive cell death during later culture times. It may thus be more likely that our culture conditions favor the differentiation of neurons and muscle cells rather than of other cell types. Many mutations in genes involved in neurogenesis of the ventral nervous system result in an overproduction of neurons at the expense of other ectodermal derivatives (Campos-Ortega, 1982). It may be possible that our culture conditions mimic the phenotype of these mutants by diluting out a factor necessary to direct the differentation of non-neuronal ectodermal cell types. Seecof (1977) has proposed that neurons and muscle cells are among the earliest cell types determined in Drosophila, and thus the other cell types may not receive the appropriate differentiation stimulus in culture. It should also be noted, however, that neuronal and muscle cell precursors are among the few mitotically active cell types in Drosophila after completion of gastrulation.

In in vivo studies of insect neuronal differentiation, one striking feature that has been studied intensively is the precise stereotypical growth of axons (Thomas et al., 1984). In dissociated 
cell cultures, it is unlikely that all the factors responsible for normal axon guidance are present; however, some of the proposed mechanisms responsible for precise axon guidance in vivo may also be present in cultures. The pattern of neuronal process elaboration in vitro often shows neuronal process growth along myotube surfaces. These processes terminate on other neuron clusters, rather than on myotubes. In addition, the processes emanating from clusters of neurons usually appear thicker than those from individual or paired neuronal cells, perhaps indicating a bundling of individual fibers, as seen in vivo. Some neuronal cell processes also appear to exhibit a rather tortuous pattern of growth, bypassing nearby cells for more distant partners.

In addition to the normal programs of cell division and HRPlike antigen expression, dissociated Drosophila gastrula-stage embryo cell cultures seem to express a similar chemical differentiation pattern in vivo and in vitro for 2 important neurotransmitter-metabolizing enzymes (ChAT and AChE). This feature of culture differentiation may seem surprising at first, since the dissociated cells are in a radically different environment in vitro. Perhaps insect cells merely unfold a genetically predetermined differentiation program without any reference to environmental cues. This possibility seems unlikely, however, in view of our results when the culture environment is altered with "cholinoactive" drugs or conditioned medium. In addition, Seecof and Dewhurst (1974) have shown that addition of insulin to the culture media is a requirement for diffcrentiation to proceed. It thus seems likely that differentiating Drosophila embryo cells not only respond creatively to environmental stimuli, but may also recognize some of the same chemical agents that normally function in vertebrates.

It is now generally believed that soluble factors produced by normal or experimentally tested target cells are of prime importance in specifying the neurons" initial "decision" with respect to transmitter phenotype, both in vivo and in vitro (Patterson and Chun, 1974; Black et al., 1984). In addition, these factors have also been implicated in later stages of neuron development when the transmitter phenotype has been observed to undergo plastic changes (Patterson, 1978; Black et al., 1984). Perhaps the decreased expression of ChAT observed following the addition of cholinoactive drugs is accompanied by a corresponding increase in some other neurotransmitter phenotype, since the cultures appear healthy and have approximately the same number of morphologically differentiated neurons. All of the cholinergic drugs we have tested could exert a common effect by virtue of their ability to block cholinergic transmission. This blocking effect could result from direct receptor blockade (i.e., via dTC, SCOP) or indirect receptor blocking through a desensitization mechanism (i.e., CARB, BW284C51). If the cholinergic receptors of target cells are indeed blocked under our chronic drug-exposure conditions, then the potential cholinergic neuron may not be getting a proper feedback signal, which would allow full expression of the ChAT gene. Many investigations have shown a profound effect of use-dependent modifications on various neuronal processes. We are now testing a number of other neuroactive drugs, such as channel and uptake blockers, for their ability to perturb the normal expression of ChAT and AChE, in the hope of defining the neurobiological mechanism underlying decreased ChAT and AChE expression.

Alternative transmitter phenotypes may also be selected when the cultures are exposed to conditioned medium. It is possible that $\mathrm{ACh}$ is one of the first neurotransmitters selected, since the levels of ChAT activity increase rapidly at about the time that clustered neuronal cells in our cultures send out processes that contact adjacent clusters. The factor or factors that allow selection of other transmitter phenotypes may thus be present in greater concentration in older cultures and influence undecided neurons to select a noncholinergic phenotype. We have not yet examined this possibility directly, since it is difficult to determine what "other" neurotransmitter phenotypes to assay. It should be mentioned, however, that the cultures make a number of other putative neurotransmitters, including histamine, dopamine, and serotonin (Salvaterra and McCaman, unpublished observations).

Most other studies that have assessed the neurotransmitter phenotype of cultured neurons after exposure to conditioned media have added media conditioned by target cells. In our experiments it is impossible to separate the neurons from their targets, since they seem to be contacting one another. The recent demonstration by Furst and Mahowald (1985a, b) of a centrifugal elutriation procedure for preparing pure neuronal cultures will perhaps be useful, at least in simplifying the cell types used to condition media. It will also be essential, in order to completely define the media we now use, to eliminate serum to arrive at a better understanding of the chemical nature of the factors necessary to permit neuronal differentiation from primary gastrula-stage embryo cells.

In summary, we have presented evidence for the operation of normal cell-division cycles, HRP-like antigen expression, and the developmental program for ChAT and $\mathrm{AChE}$ gene expression in in vitro cultures of Drosophila early gastrula-stage embryo cells. This program for transmitter-metabolizing enzymes is not unalterably fixed, but can be modified by culturing the differentiating cells in the presence of a number of cholinoactive drugs or conditioned media. The genes for both of these neurotransmitter-metabolizing macromolecules have been mapped in Drosophila, and several mutant alleles are available (Greenspan, 1980; Greenspan et al., 1980). We have recently obtained a ChAT cDNA clone (Itoh et al., 1986) from Drosophila, and it will now be possible to examine its expression pattern in more detail at the transcriptional level using cultured embryo cells from wild-type, as well as mutant, embryos (Seecof, 1977). By combining the considerable genetic advantages of Drosophila with in vitro techniques, it should be possible to experimentally attack the problems presented by the complex interaction of the environment and genes during development.

\section{References}

Black, I. B. (1982) Stages of neurotransmitter development in autonomic neurons. Science 215: 1198-1204.

Black, I. B., J. E. Adler, M. C. Bolin, G. M. Jonaleait, J. A. Kessler, and K. A. Markey (1984) Transmitter phenotype plasticity in developing and mature neurons in vivo. In Cellular and Molecular Biology of Neuronal Development, I. B. Black, ed., pp. 117-130, Plenum, New York.

Bournias-Vardiabasis, N., R. L. Teplitz, G. F. Chernoff, and R. L. Seecof (1983a) Detection of teratogens in the Drosophila embryonic cell culture test: Assay of 100 chemicals. Teratology 18: 109-122.

Bournias-Vardiabasis, N., C. H. Buzin, and J. G. Reilly (1983b) The effect of 5-azacytidine and cytidine analogs on Drosophila melanogaster cells in culture. Roux's Arch. Dev. Biol. 192: 299-302.

Buzin, C. H., and N. Bournias-Vardiabasis (1984) Teratogens induce a subset of small heat shock proteins in Drosophila primary embryonic cell cultures. Proc. Natl. Acad. Sci. USA 81: 4075-4079.

Campos-Ortega, J. A. (1982) Development of the nervous system. In 
Handbook of Drosophila Development, R. Ransom, ed., pp. 153-181, Elsevier, Amsterdam, New York, Oxford.

Cross, D. P., and J. H. Sang (1978a) Cell culture of individual Drosophila embryos. I. Development of wild-type cultures. J. Embryol. Exp. Morphol. 45: 161-172.

Cross, D. P., and J. H. Sang (1978b) Cell culture of individual Drosophila embryos. II. Culture of X-linked embryonic lethals. J. Embryol. Exp. Morphol. 45: 173-187.

Dewhurst, S. A., and R. L. Seecof (1975) Development of acetylcholine metabolizing enzymes in Drosophila embryos and in cultures of Drosophila cells. Comp. Biochem. Physiol. 50C: 53-58.

Dewhurst, S., and R. L. Seecof (1979) Reactions programming enzyme production during Drosophila neurogenesis. Insect. Biochem. 9:49_ 54.

Dietz, G. W., and P. Salvaterra (1980) Purification and peptide mapping of rat brain choline acetyltransferase. J. Biol. Chem. 255: 1061210617.

Dudai, Y., and J. Ben-Barak (1977) Muscarinic receptor in Drosophila melanogaster demonstrated by binding of $\left[{ }^{3} \mathrm{H}\right]$ quinuclidinyl benzilate. FEBS Lett. 81: 134-136.

Ellman, G. L., K. D. Courtney, V. Andres, and R. M. Feathersteon (1961) A new and rapid colorimetric determination of acetylcholinesterase activity. Biochem. Pharmacol. 7: 88-95.

Fonnum, F. (1975) A rapid radiochemical method for the determination of choline acetyltransferase. J. Neurochem. 24: 407-409.

Furshpan, E. J., P. R. MacLeish, P. H. O'Lague, and D. D. Potter (1976) Chemical transmission between rat sympathetic neurons and cardiac myocytes developing in micro-cultures. Evidence for cholinergic, adrenergic and dual function neurons. Proc. Natl. Acad. Sci. USA 73: 4225-4229.

Furst, A., and A. P. Mahowald (1984) Rapid immunofluorescent screening procedure using primary cell cultures or tissue sections. J. Immunol. Methods 70: 101-109.

Furst, A., and A. P. Mahowald (1985a) Differentiation of primary neuroblasts in purified neural cell cultures from Drosophila. Dev. Biol. 109: 184-192.

Furst, A., and A. P. Mahowald (1985b) Cell division cycle of cultured neural precursor cells from Drosophila. Dev. Biol. 112: 467-476.

Gerson, I., R. L. Seecof, and R. L. Teplitz (1976) Ultrastructural differentiation during neurogenesis in vitro. J. Neurobiol. 7:447-455.

Greenspan, R. (1980) Mutations of choline acetyltransferase and associated neural defects in Drosophila melanogaster. J. Comp. Physiol. 137: 83-92.

Greenspan, R. J., J. A. Finn, Sr., and J. C. Hall (1980) Acetylcholinesterase mutants in Drosophila and their effects on the structure and function of the central nervous system. J. Comp. Neurol. 189: 741774.

Hall, J. C., and D. R. Kankel (1976) Genetics of acetylcholinesterase in Drosophila melanogaster. Genetics 83: 517-533.

Hartenstein, V., and J. A. Campos-Ortega (1984) Early neurogenesis in wild-type Drosophila melanogaster. Roux's Arch. Dev. Biol. 193: 308-325.

Itoh, N., J. R. Slemmon, D. H. Hawke, R. Williamson, E. Morita, K. Itakura, E. Roberts, J. E. Shively, G. D. Crawford, and P. M. Salvaterra (1986) Cloning of Drosophila choline acetyltransferase cDNA. Proc. Natl. Acad. Sci. USA 83: 4081-4085.

Jan, L. Y., and Y. N. Jan (1982) Antibodies to horseradish peroxidase as specific neuronal markers in Drosophila and grasshopper embryos. Proc. Natl. Acad. Sci. USA 79: 2700-2704.

Jimenez, F., and J. A. Campos-Ortega (1979) A region of the Drosophila genome necessary for CNS development. Nature 282: 310 311.

Karnovsky, M. J., and L. Roots (1964) A direct coloring method for cholinesterases. J. Histochem. Cytochem. 12: 219-221.

Landis, S. C., and D. Keefe (1983) Evidence of neurotransmitter plasticity in vivo: Developmental changes in properties of cholinergic sympathetic neurons. Dev. Biol. 98: 349-371.

LeDourain, N. M., M.-A. Teillet, and C. Le Lievre (1977) Influence of tissue environment on the differentiation of neural crest cells. In Cell and Tissue Interactions, J. W. Walsh and M. M. Burger, eds., pp. 11-27, Raven, New York.
Lehman, R., U. Dietrich, F. Jimenez, and J. A. Campos-Ortega (1981) Mutations of early neurogenesis in Drosophila. Roux's Arch. Dev. Biol. 190: 226-229.

Lowry, O. H., N. J. Rosebrough, A. L. Farr, and R. J. Randall (1951) Protein measurement with the Folin phenol reagent. J. Biol. Chem. 193: 265-275.

Patterson, P. H. (1978) Environmental determination of autonomic neurotransmitter function. Annu. Rev. Neurosci. 1: 1-17.

Patterson, P. H., and L. L. Y. Chun (1974) The influence of nonneuronal cells on catecholamine and acetylcholine synthesis and accumulation in cultures of dissociated sympathetic neurons. Proc. Natl. Acad. Sci. USA 71: 3607-3610.

Patterson, P. H., and L. L. Y. Chun (1977) The induction of acetylcholine synthesis in primary cultures of dissociated sympathetic neurons. II: Developmental aspects. Dev. Biol. 60: 473-481.

Poulson, D. F. (1950) Histogenesis, organogenesis and differentiation in the embryo of Drosophila melanogaster meigen. In Biology of Drosophila, M. Demerc, ed., pp. 168-274, Wiley, New York.

Salvaterra, P. M., and R. M. Foders (1979) [ $\left.{ }^{125} \mathrm{I}\right] \alpha$-bungarotoxin and $\left[{ }^{3} \mathrm{H}\right]$ quinuclidinyl benzilate binding in central nervous systems of different species. J. Neurochem. 32: 1509-1517.

Seecof, R. L. (1977) A genetic approach to the study of neurogenesis and myogenesis. Am. Zool. 17: 577-584.

Seecof, R. L. (1980) Preparation of cell cultures from Drosophila melanogaster embryos. Tissue Culture Association Manual 5: 1019-1022.

Seecof, R. L., and S. Dewhurst (1974) Insulin is a Drosophila hormone and acts to enhance the differentiation of embryonic Drosophila cells. Cell Differ. 3: 63-70.

Seecof, R. L., and S. A. Dewhurst (1976) A 5-bromodeoxyuridinesensitive interval during Drosophila myogenesis. Differentiation 6: 27-32.

Seecof, R. L., and R. L. Unanue (1968) Differentiation of embryonic Drosophila cells in vitro. Exp. Cell Res. 50:654-660.

Seecof, R. L., N. Alleaume, R. L. Teplitz, and I. Gerson (1971) Differentiation of neurons and myocytes in cell cultures made from Drosophila gastrulae. Exp. Cell Res. 69: 161-173.

Seecof, R. L., R. L. Teplitz, K. Ikeda, and J. J. Donady (1972) Differentiation of neuromuscular junctions in cultures of embryonic Drosophila cells. Proc. Natl. Acad. Sci. USA 69: 556-670.

Seecof, R. L., J. J. Donady, and R. L. Teplitz (1973a) Differentiation of Drosophila neuroblasts to form ganglion-like clusters of neurons in vitro. Cell Differ. 2: 143-149.

Seecof, R. L., J. J. Donady, and P. Toribio-Fiorio (1973b) Formation of axon to myocyte contacts in Drosophila cell cultures. Am. Zool. 13: 331-336.

Seecof, R. L., I. Gerson, J. J. Donady, and R. L. Teplitz (1973c) Drosophila myogenesis in vitro: The genesis of small myocytes and myotubes. Dev. Biol. 35: 250-261.

Shields, G., and J. H. Sang (1970) Characteristics of five cell types appearing during in vitro culture of embryonic material from Drosophila melanogaster. J. Embryol. Exp. Morphol. 23: 53-69.

Shields, G., A. Dubendorfer, and J. H. Sang (1975) Differentiation in vitro of larval cell types from early embryonic cells of Drosophila melanogaster. J. Embryol. Exp. Morphol. 33: 159-175.

Slemmon, J. R., K. Saito, and P. M. Salvaterra (1980) Preparation and characterization of peroxidase: Anti-peroxidase-Fab complex. J. Histochem. Cytochem. 28: 10-15.

Thomas, J. B., M. J. Bastiani, M. Bate, and C. Goodman (1984) From grasshopper to Drosophila a common plan for neuronal development. Nature 310: 203-207.

White, K. (1980) Defective neural development in Drosophila melanogaster embryos deficient for the tip of the X chromosome. Dev. Biol. 80: 332-344

Wright, T. R. F. (1970) The genetics of embryogenesis in Drosophila. Adv. Genet. 15: 261-395.

Yoshitake,Y., K. Nishikawa, and K. Adachi (1982) DNA synthesisstimulating activities for BALB/3T3 cells present in histone and nonhistone protein fractions from rat rhodamine fibrosarcoma. Cell. Struct. Funct. 7: 229-243. 